\title{
Pengaruh Tingkat Hutang, Fee Audit, dan Konsentrasi Pasar \\ Pada Persistensi Laba
}

\author{
Made Edi Mahendra ${ }^{1}$ \\ Fakultas Ekonomi dan Bisnis \\ Universitas Udayana, Indonesia \\ Email: edimahendra1811@gmail.com
}

\author{
I Made Sadha Suardikha ${ }^{2}$ \\ Fakultas Ekonomi dan Bisnis \\ Universitas Udayana, Indonesia
}

\begin{abstract}
ABSTRAK
Tujuan penelitian ini adalah untuk mengetahui pengaruh tingkat hutang, fee audit, dan konsentrasi pasar pada persistensi laba. Penelitian ini dilakukan pada perusahaan transportasi yang terdaftar di Bursa Efek Indonesia dari tahun 2014 sampai 2017. Jumlah sampel yang diambil sebanyak 9 perusahaan dengan menggunakan metode non probability sampling dengan teknik purposive sampling. Teknik analisis data yang digunakan adalah analisis regresi linier berganda. Berdasarkan hasil analisis ditemukan bahwa tingkat hutang, fee audit, dan konsentrasi pasar berpengaruh positif pada persistensi laba.
\end{abstract}

Kata Kunci: Tingkat Hutang; Fee Audit; Konsentrasi Pasar; Persistensi Laba.

\section{Effect of Debt Levels, Audit Fees, and Market Concentration on earnings Persistence}

\section{ABSTRACT}

This study aims to determine whether the level of debt, audit fees, and market concentration affect earnings persistence. This research was conducted on transportation companies listed on the Indonesian stock exchange from 2014 to 2017. The number of samples taken as many as 9 companies using non-probability sampling method with purposive sampling technique. The analysis technique used is multiple linear regression. Based on the results of the analysis found that the level of debt, audit fees, and market concentration has a positive effect on earnings persistence.

Keywords: Debt Levels; Audit Fees; Market Concentration; Earnings Persistence.

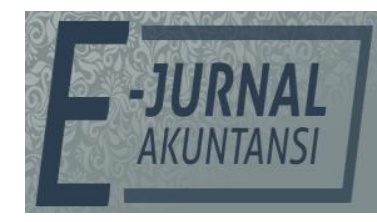

E-JA

e-Jurnal Akuntansi e-ISSN 2302-8556

Vol. 30 No. 1

Denpasar, Januari 2020

Hal. 179-193

Artikel Masuk: 13 November 2019

Tanggal Diterima: 28 Desember 2019 


\section{PENDAHULUAN}

Laporan keuangan merupakan catatan informasi keuangan perusahaan pada suatu periode akuntansi yang dapat digunakan untuk menggambarkan kinerja perusahaan. Kualitas dari suatu laporan keuangan pada umumnya diperlukan oleh investor dan kreditor yang menggunakan laporan keuangan untuk pengambilan keputusan investasi (Putri \& Supadmi, 2016). Salah satu elemen dari laporan keuangan yang digunakan sebagai dasar pengambilan keputusan adalah informasi laba. Informasi laba merupakan hal yang sangat penting bagi pihak-pihak yang terkait dalam perusahaan, dalam menaksir laba perusahaan di masa yang akan datang (Sutisna, 2017). Begitu besarnya peranan dari informasi laba, maka kualitas laba menjadi hal yang sangat penting bagi para pengambil keputusan. kualitas laba merupakan kemampuan laba dalam merefleksikan kebenaran laba perusahaan dan membantu memprediksi laba mendatang, dengan mempertimbangkan stabilitas dan persistensi (Utari \& Mertha, 2016).

Komponen dari kualitas laba adalah persistensi laba. Kualitas laba ditentukan berdasarkan karakteristik kualitatif dalam rerangka konseptual, sifat runtun waktu dari laba, keputusan implementasi, serta hubungan antara laba, kas, dan proses akrual (Jumiati \& Ratnadi, 2014). Persistensi laba tergolong dalam sifat runtun waktu dari laba, dimana informasi laba harus mampu membuat perbedaan dalam pengambilan keputusan dengan membantu pengguna untuk melakukan prediksi dari masa lalu, sekarang, dan untuk masa depan (Zdulhiyanov, 2015). Persistensi laba merupakan laba yang cenderung tidak berfluktuatif dan mencerminkan laba yang berkesinambungan di masa depan untuk periode yang lama (Hui, Nelson, \& Yeung, 2016). Perusahaan yang memiliki laba tidak stabil dan laba yang berfluktuasi menurun curam hingga mengalami kerugian dalam waktu yang singkat menunjukkan bahwa perusahaan tersebut tidak dapat mencerminkan laba yang persisten (Putri \& Supatmini, 2016).

Indikator laba pada periode mendatang dengan komponen nilai predisksi suatu laba guna menilai kinerja perusahaan dalam jangka panjang dapat didefinisikan sebagai persistensi laba. Persistensi laba merupakan salah satu unsur yang sangat relevan dan dapat mencerminkan tujuan dari informasi laba, seperti yang dikatakan dalam conceptual framework FASB tujuan dari informasi laba adalah memberikan informasi yang berguna bagi pembuatan keputusan oleh investor dan kreditor (Fanani, Ningsih, \& Hamidah, 2008). Persistensi laba berhubungan dengan kinerja perusahaan yang digambarkan melalui laba perusahaan, dimana laba yang persisten terefleksi pada laba yang dapat berkesinambungan dalam periode yang lama (Arisandi \& Astika, 2019).

Pengguna informasi keuangan perusahaan tentunya mengharapkan perusahaan memiliki laba yang persisten, karena laba yang tidak persisten akan menimbulkan masalah ketidaktepatan dalam pengambilan keputusan yang didasarkan pada kondisi di masa depan (Zhou, 2016). Fenomena laba yang tidak persisten telah terjadi pada perusahaan yang tergolong strategis di Indonesia yaitu perusahaan transportasi. Perusahaan transportasi merupakan perusahaan yang berperan penting dalam kegiatan pendistribusian orang dan barang di Indonesia. Negara Indonesia merupakan Negara kepulauan dengan luas daratan 2,01 juta $\mathrm{km}^{2}$ dan luas perairan 3,25 juta $\mathrm{km}^{2}$ (Diakses: KKP, 2017), sehingga 
distribusi orang dan barang di Indonesia tidak dapat dihindarkan. Dengan tingginya kebutuhan transportasi di Indonesia, diyakini dapat meningkatkan perolehan laba yang persisten pada perusahaan transportasi di indonesia. Namun, dalam kenyataanya sejak tahun 2014 perusahaan transportasi yang terdaftar di BEI mengalami fluktuasi laba atau laba yang tidak stabil yang menggambarkan bahwa laba perusahaan tersebut tidak persisten, seperti yang ditunjukkan pada gambar 1 berikut ini.

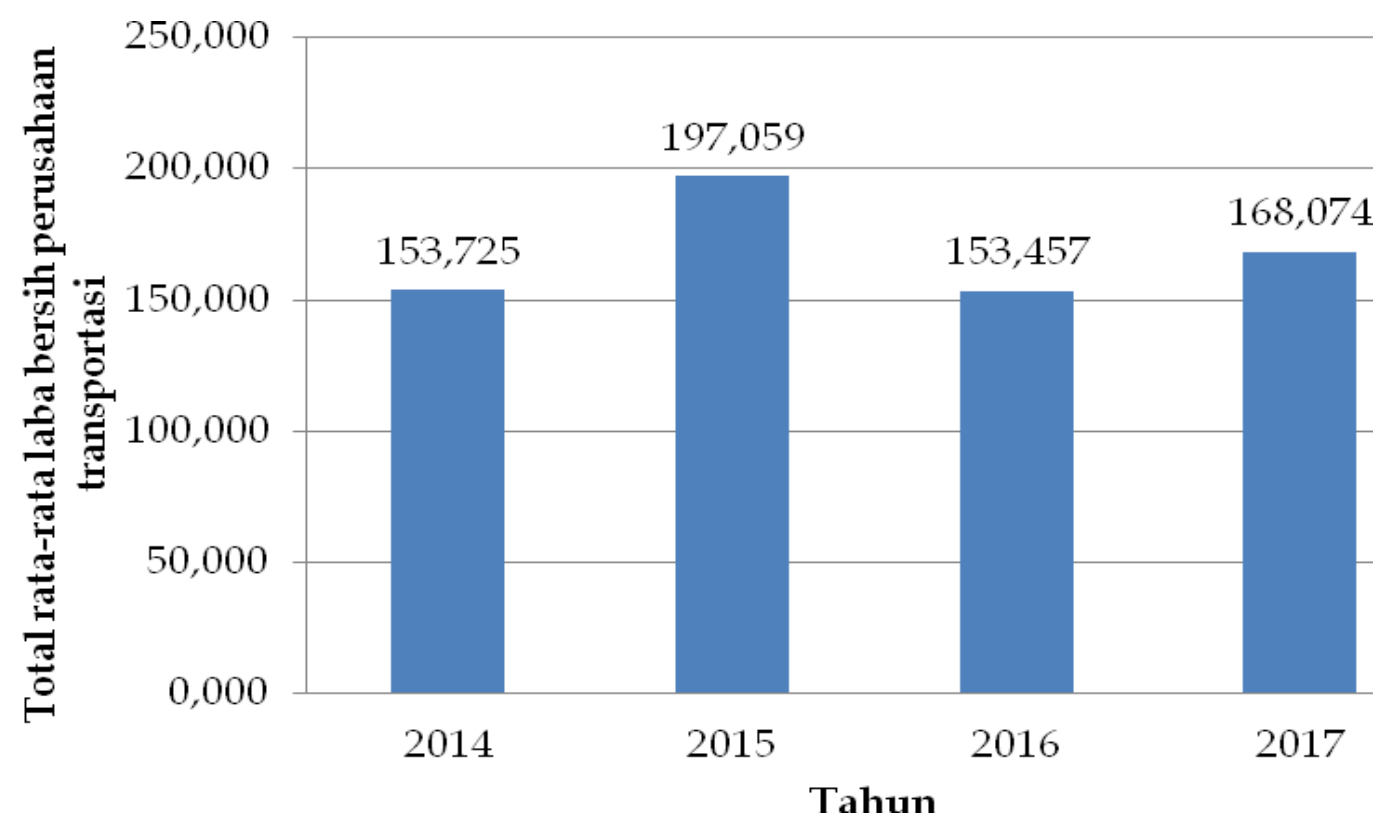

\section{Gambar 1. Total rata-rata laba bersih perusahaan transportasi di BEI tahun 2014-2017 dalam juta rupiah.}

Sumber: Data Penelitian, 2019

Gambar 1 merupakan rata-rata laba bersih perusahaan transportasi di BEI dari tahun 2014-2017 kecuali perusahaan yang tergolong BUMN. Perusahaan BUMN merupakan perusahaan yang padat regulasi. Proses bisnis pada perusahaan BUMN berlangsung tidak secara normal, hampir seluruh kegiatan perusahaan ditentukan oleh pemerintah. Laba bersih yang diperoleh perusahaan transportasi BUMN yang terdaftar di BEI dari tahun 2014-2017, yaitu PT Garuda Indonesia (persero) Tbk secara berturut-turut dalam juta rupiah adalah sebesar Rp.4.589.256, Rp.1.075.654, Rp.125.826, dan -Rp.2.891.003 (Diakses: idx.co.id). Data laba bersih tersebut membuktikan bahwa PT Garuda Indonesia (persero) Tbk mengalami fluktuasi laba yang tinggi, sehingga jika dimasukkan kedalam perhitungan rata-rata laba bersih perusahaan BUMN akan mendominasi terjadinya fluktuasi laba. Pada gambar grafik batang di atas terlihat bahwa total rata-rata laba bersih perusahaan transportasi di BEI dari tahun 2014-2017 selalu berubah-ubah dalam jangka waktu yang singkat, hal ini menggambarkan bahwa perusahaan tidak dapat mencerminkan keberlanjutan laba di masa depan (Zhou, 2016).

Laba yang persisten dapat diperoleh perusahaan melalui dua cara, cara pertama dengan memperhatikan indikator-indikator yang dapat memengaruhi 
terjadinya persistensi laba pada perusahaan dan cara kedua dengan melakukan praktik perataan laba. Praktik perataan laba merupakan salah satu tindakan rekayasa manajemen untuk menekan jumlah laba pada sejumlah periode tertentu dengan tujuan untuk memperoleh tingkat laba sesuai dengan yang diharapkan (Djajanti, 2017). Pengurangan atau penambahan laba dilakukan karena adanya perbedaan antara laba yang seharusnya dilaporkan dengan laba yang diharapkan perusahaan. Perataan laba adalah suatu kegiatan rekayasa yang dilakukan oleh manajemen perusahaan sehingga laba yang dihasilkan memiliki fluktuasi yang relatif rendah dan stabil setiap periodenya atau sering dikatakan sebagai laba yang persisten (Koch, 1981). Perataan laba dilakukan bertujuan untuk menarik investor dan kreditor agar tetap menginvestasikan kekayaannya mereka untuk perusahaan, tetapi hal ini menjadi suatu hal yang merugikan bagi para investor dan kreditor karena investor dan kreditor tidak mendapatkan informasi yang sesungguhnya terjadi yang nantinya akan digunakan sebagai dasar untuk pengambilan keputusan investasi. Investor dan kreditor perlu berhati-hati dalam melihat laba yang persisten pada perusahaan, karena laba yang persisten tersebut mungkin saja terjadi dikarenakan adanya praktik perataan laba yang dilakukan perusahaan, oleh karena itu investor dan kreditor perlu memperhatikan indikator-indikator yang dapat memengaruhi terjadinya persistensi laba agar terhindar dari perusahaan yang menggunakan praktik perataan laba.

Terdapat beberapa indikator yang dapat memengaruhi terjadinya persistensi laba seperti book-tax differences, kepemilikan manajerial, ukuran perusahaan, besaran akrual, volatilitas aliran kas, tingkat hutang, fee audit dan konsentrasi pasar, namun peneliti hanya menggunakan tiga indikator yang dapat memengaruhi persistensi laba yaitu tingkat hutang, fee audit dan konsentrasi pasar, dikarenakan indikator yang lainnya telah beberapa kali diteliti oleh peneliti sebelumnya dan hasilnya telah konsesten, selain itu peneliti ingin menkonfirmasi kembali terkait variabel-variabel yang digunakan dalam penelitian ini.

Adapun indikator-indikator yang dapat memengaruhi terjadinya persistensi laba, salah satunya yaitu Tingkat Hutang. Hutang merupakan bagian dari upaya perusahaan untuk memperoleh laba (Rahmadhani, Zulbahridar, \& Hariadi, 2016). Jika dana internal tidak mencukupi untuk memenuhi seluruh kegiatan operasional perusahaan guna memperoleh laba yang maksimal, pihak perusahaan akan melakukan penarikan dana dari pihak eksternal dengan cara meminjam atau hutang. Dengan tingginya tingkat hutang disuatu perusahaan akan meningkatkan motivasi pihak manajemen untuk meningkatkan persistensi laba yang bertujuan untuk mempertahankan kinerja keuangan perusahaan (Sulastri, 2014). Penelitian yang dilakukan oleh Putri \& Supadmi (2016) serta Fitriana \& Fadhila (2016) menghasilkan bahwa tingkat utang berpengaruh positif pada persistensi laba. Sedangkan penelitian yang dilakukan oleh Achyarsyah \& Purwanti (2018) menghasilkan bahwa tingkat utang berpengaruh negatif pada persistensi laba. Sementara itu penelitian yang dilakukan oleh Arisandi \& Astika (2019), menghasilkan bahwa tingkat utang tidak berpengaruh pada persistensi laba. 
Indikator kedua dalam penelitian ini yang dapat memengaruhi persistensi laba adalah fee audit. Besar kecilnya fee audit yang telah disepakati oleh auditor dengan kliennya kemungkinan besar akan memengaruhi kualitas audit yang dihasilkannya. Dengan tingginya fee audit akan meningkatkan ketelitian auditor dalam proses pemeriksan laporan keuangan serta dapat memperluas prosedur audit yang digunakan dalam proses pemeriksaan laporan keuangan (Nuraeni, Mulyati, \& Putri, 2018). Peningkatan kegiatan auditor tersebut akan membawa dampak positif bagi manajemen perusahaan, hal tersebut dapat memotivasi manajemen perusahaan untuk meminimalisir praktik kecurangan di dalam perusahaan yang nantinya akan berdampak pada peningkatan kualitas laba dan menggambarkan laba yang persisten pada perusahaan. Penelitian yang dilakukan oleh El-Gammal (2012) membuktikan bahwa pemberian fee audit yang besar kepada auditor independen akan memengaruhi kualitas audit yang dihasilkan oleh auditor independen. Penelitian yang dilakukan oleh Nuraeni et al (2018) menyatakan bahwa fee audit berpengaruh positif pada persistensi laba.

Indikator ketiga dalam penelitian ini yang dapat memengaruhi persistensi laba selain tingkat hutang dan fee audit adalah konsentrasi pasar. Suatu perusahaan yang dikatakan telah memiliki konsentrasi pasar yang tinggi jika perusahaan tersebut telah menguasai sebagian besar pangsa pasar serta perusahaan tersebut relatif terhadap pangsa pasar. Jika pangsa pasar perusahaan tinggi perusahaan mempunyai posisi kuat dalam kompetisi, perusahaan akan memberikan sinyal tentang masa depan perusahaan yang lebih baik melalui persistensi labanya (Fanani et al., 2008). Penelitian yang dilakukan oleh Fanani et al (2008) yang menyatakan bawah konsentrasi pasar berpengaruh positif terhadap kualitas pelaporan keuangan berbasis akuntansi yang diproksikan dengan persistensi, prediktibilitas dan perataan. Hasil yang sama juga ditunjukkan penelitian yang dilakukan oleh Nuraeni et al (2018) yang menyatakan bahwa konsentrasi pasar berpengaruh positif terhadap persistensi laba.

Berdasarkan teori keagenan, penerbitan hutang (obligasi) dapat mengurangi terjadinya asimetri informasi antara manajemen perusahaan dengan stakeholder perusahaan. Asimetri informasi ini terjadi karena terdapat kesenjangan informasi terkait tingginya harga saham baru yang di terbitkan oleh perusahaan yang tidak menggambarkan kondisi yang sebenarnya dari perusahaan. oleh karena itu penerbitan hutang (obligasi) lebih diutamakan dibandingkan dengan penerbitan saham baru untuk meminimalisir terjadinya asimetri informasi antara manajemen perusahaan dengan stakeholder perusahaan. Tingginya tingkat hutang di suatu perusahaan menggambarkan tingginya penerbitan hutang (obligasi) perusahaan tersebut. Perusahaan yang memilih hutang sebagai pendanaan eksternalnya dituntut untuk dapat meningkatkan persistensi labanya dengan tujuan dapat meningkatkan kinerja perusahaan yang nantinya akan dipandang baik oleh kreditor, selain itu diharapkan dapat memberikan keuntungan bagi perusahaan, sehingga perusahaan dapat berkembang serta dapat membayar kembali hutang tersebut kepada kreditur dengan bunga yang telah disepakati bersama (Enekwe, Agu, \& Nagbogu, 2014). Keditor dan investor cenderung akan menilai baik terhadap perusahaan dengan 
tingkat hutang yang tinggi apabila laba perusahaan tersebut persisten dan sesuai dengan kondisi yang sebenarnya dan berkelanjutan.

Penelitian yang dilakukan oleh Fitriana \& Fadhlia (2016) mendukung pernyataan diatas dengan menyatakan tingkat utang berpengaruh positif pada persistensi laba, ini berarti jika semakin tinggi tingkat hutang dalam suatu perusahaan, maka semakin tinggi persistensi laba pada perusahaan tersebut. Besarnya tingkat hutang perusahaan akan menyebabkan perusahaan meningkatkan persistensi laba dengan tujuan untuk mempertahankan kinerja yang baik dimata investor dan auditor. Hasil yang sama juga ditunjukkan penelitian yang dilakukan oleh Putri \& Supadmini (2016) yang menyatakan bahwa tingkat hutang berpengaruh positif pada peristensi laba. Berdasarkan uraian di atas, maka hipotesis penelitian ini adalah:

$\mathrm{H}_{1}$ : Tingkat Hutang berpengaruh positif pada Persistensi Laba.

Berdasarkan teori sinyal, besarnya fee audit suatu perusahaan dapat memberikan sinyal perusahaan kepada ekternal perusahaan mengenai kemampuan perusahaan menghasilkan laba yang persisten. Hal ini dikarenakan adanya tingkat ketelitian yang tinggi dari seorang auditor independen serta auditor independen dapat memperluas prosedur auditnya dengan seksama sehingga kecurangan-kecurangan yang mungkin terjadi pada laporan keuangan perusahaan tidak akan terlewati dan auditor independen akan menghasilkan laporan audit yang berkualitas. Maka dari itu pihak manajemen perusahaan akan termotivasi untuk meningkatkan kinerja perusahaannya dengan melaporkan laba yang persisten dan dapat menghilangkan praktek kecurangan serta perataan laba dalam perusahaan.

Penelitian yang dilakukan oleh El-Gammal (2012) mendukung teori diatas, dimana penelitian tersebut membuktikan bahwa perusahaan multinasional dan bank-bank di Lebanon lebih memilih untuk membayar biaya audit yang bernominal besar dengan alasan yaitu mereka lebih mencari auditor dalam kantor akuntan publik yang dapat menghasilkan laporan audit yang berkualitas sehingga dapat mencerminkan persistensi laba pada perusahaan dan dapat meningkatkan kredibilitas laporan keuangan tahunan yang dapat bersaing diseluruh dunia. Teori diatas juga didukung oleh penelitian yang dilakukan Nuraeni et al (2018) yang menyatakan bahwa fee audit berpengaruh positif terhadap perisistensi laba, pemberian fee audit yang besar dapat meningkatkan ketelitian auditor dalam proses pemeriksaan serta dapat tersedia dana untuk penerapan prosedur audit yang lebih luas dan seksama. Maka dari itu pihak manajemen perusahaan akan termotivasi untuk meningkatkan kinerja perusahaan, salah satunya dengan melaporkan laba yang persisten dan mengurangi praktik manjemen laba. Berdasarkan uraian di atas, maka hipotesis penelitian ini adalah:

$\mathrm{H}_{2}$ : Fee audit berpengaruh positif pada persistensi laba.

Berdasarkan teori sinyal, konsentrasi pasar perusahaan sangat erat kaitannya dengan persentase pangsa pasar yang dikuasai oleh perusahaan terhadap pangsa pasar total. Semakin besar pangsa pasar perusahaan maka semakin tinggi tingkat konsentrasi pasar perusahaan tersebut. Pangsa pasar bersinggungan langsung dengan laba, hal tersebut dikarenakan adanya kegiatan penjualan dalam pangsa pasar. Semakin besar penjualan perusahaan, dan 
perusahaan dapat mempertahankan penjualan maka akan memengaruhi laba perusahaan. Jika konsentrasi pasar perusahaan besar perusahaan mempunyai posisi kuat dalam kompetisi sehingga perusahaan akan memberikan sinyal tentang masa depan perusahaan yang lebih baik melalui persistensi labanya (Fanani et al., 2008).

Teori diatas didukung oleh penelitian yang dilakukan oleh Fanani et al (2008) yang menyatakan bawah konsentrasi pasar berpengaruh positif terhadap kualitas pelaporan keuangan berbasis akuntansi yang diproksikan dengan persistensi, prediktibilitas dan perataan. Hasil yang sama juga ditunjukkan penelitian yang dilakukan oleh Nuraeni et al (2018) yang menuyatakan bahwa konsentrasi pasar berpengaruh positif terhadap persistensi laba. Hal ini berarti semakin tinggi tingkat konsentrasi pasar suatu perusahaan serta perusahaan dapat mempertahankan hingga meningkatkan tingkat konsentrasi pasarnya maka akan memengaruhi terjadinya persistensi laba pada perusahaan. Berdasarkan uraian di atas, maka hipotesis penelitian ini adalah:

$\mathrm{H}_{3}$ : Konsentrasi pasar berpengaruh positif pada persistensi laba.

\section{METODE PENELITIAN}

Penelitian ini dilakukan pada perusahaan transportasi yang terdaftar di BEI pada tahun 2014-2017, dengan data yang diakses melalui www.idx.co.id serta website perusahaan transportasi yang menjadi sampel dalam penelitian ini. Variabel dependen dalam penelitian ini adalah persistensi laba, variabel independen yang digunakan dalam penelitian ini adalah tingkat hutang, fee audit, dan konsentrasi pasar.

Persistensi laba diukur dengan koefisien regresi laba sebelum pajak tahun berjalan $\left(\mathrm{PTBI}_{\mathrm{t}}\right)$ terhadap laba sebelum pajak tahun depan $\left(\mathrm{PTBI}_{\mathrm{t}+1}\right)$ dengan menggunakan analisis regresi sederhana (Jumiati \& Ratnadi, 2014). Laba sebelum pajak tahun depan $\left(\mathrm{PTBI}_{\mathrm{t}+1}\right)$ diukur dengan rumus (Jumiati \& Ratnadi, 2014): $\mathrm{PTBI}_{\mathrm{t}+1}=\frac{\text { Laba sebelumpajak tahundepar }}{\text { Totalaset }}$

Laba sebelum pajak tahun berjalan $\left(\mathrm{PTBI}_{\mathrm{t}}\right)$ diukur dengan rumus (Jumiati \& Ratnadi, 2014):

$\mathrm{PTBI}_{\mathrm{t}}=\frac{\text { Laba sebelum pajak tahun berjalar }}{\text { Total aset }}$

Tingkat hutang diukur menggunakan Debt ratio didasarkan pada acuan penelitian sebelumnya dari Putri \& Supadmi (2016) dengan rumus:

Debt Ratio $=\frac{\text { Total HutanE }}{\text { Total Aset }}$

Pengukuran fee audit dapat ditunjukkan dari besarnya jumlah professional fees yang diberikan oleh perusahaan kepada auditor independen (Nuraeni et al., 2018).

Tingkat konsentrasi pasar diukur berdasarkan acuan penelitian sebelumnya dari Nuraeni et al (2018) dengan rumus:

$\frac{\text { Pendapatan }}{\text { Total pendapatanindustri }} \times 100 \%$

Populasi yang digunakan dalam penelitian ini adalah 34 perusahaan transportasi yang terdaftar di BEI pada tahun 2014-2017. Penelitian ini dilakukan empat tahun terakhir dengan tujuan memperoleh data terbaru dan mendapatkan 
hasil yang diharapkan. Sampel yang digunakan dalam penelitian ini dipilih berdasarkan kriteria tertentu dalam metode non probability sampling dengan teknik purposive sampling.

Langkah pertama yang harus dilakukan dalam penelitian ini adalah menghitung nilai persistensi laba untuk setiap sampel perusahaan dan menguji apakah terdapat peristensi laba dalam data yang diteliti. Regresi ini dilakukan dengan variabel laba sebelum pajak tahun berjalan $\left(\mathrm{PTBI}_{t}\right)$ sebagai variabel independen dan variabel laba sebelum pajak tahun depan $\left(\mathrm{PTBI}_{t+1}\right)$ sebagai variabel dependen. Persamaan yang digunakan sebagai berikut (Jumiati \& Ratnadi, 2014).

$\mathrm{PTBI}_{\mathrm{t}+1}=\alpha+\beta \mathrm{PTBI}_{\mathrm{t}}+\mathrm{e}$

Keterangan:

$\mathrm{PTBI}_{\mathrm{t}+1}$ : laba sebelum pajak tahun depan

$\mathrm{PTBI}_{t}$ : laba sebelum pajak tahun berjalan

a $\quad$ : konstanta

$\beta \quad$ : koefisien regresi

e : error

Teknik analisis data yang digunakan dalam penelitian ini adalah uji regresi linier berganda. Analisis regresi linier berganda digunakan untuk mengetahui dan memperoleh gambaran mengenai pengaruh variabel-variabel independen yaitu tingkat hutang, fee audit, dan konsentrasi pasar pada variabel dependen yaitu persistensi laba. Persamaan regresi linier berganda dirumuskan sebagai berikut (Sugiyono, 2017:275).

$Y=\alpha+\beta_{1} X_{1}+\beta_{2} X_{2}+\beta_{3} X_{3}+e$

Keterangan :

$\begin{array}{ll}\mathrm{Y} & : \text { Persistensi Laba } \\ \mathrm{\alpha} & : \text { Konstanta } \\ \beta_{1}, \beta_{2}, \beta_{3} & : \text { Koefisien regresi variabel independen } \\ \mathrm{X}_{1} & : \text { Tingkat Hutang } \\ \mathrm{X}_{2} & : \text { Fee audit } \\ \mathrm{X}_{3} & : \text { Konsentrasi Pasar } \\ \mathrm{e} & : \text { error }\end{array}$

\section{HASIL DAN PEMBAHASAN}

Analisis regresi sederhana dilakukan dalam penelitian ini bertujuan untuk menghitung dan mengetahui adanya persistensi laba pada data yang digunakan dalam penelitian ini. Analisis regresi sederhana dilakukan dengan laba sebelum pajak tahun berjalan $\left(\mathrm{PTBI}_{\mathrm{t}}\right)$ sebagai variabel independen dan laba sebelum pajak tahun depan $\left(\mathrm{PTBI}_{\mathrm{t}+1}\right)$ sebagai variabel dependen. Pengaruh antara laba sebelum pajak tahun berjalan dengan laba sebelum pajak tahun depan yang mengindikasikan adanya persistensi laba dapat ditunjukkan apabila hasil regresi variabel tersebut menunjukkan nilai signifikansi kurang dari 0,05. Pengaruh yang terjadi antar variabel tersebut menunjukkan kesinambungan laba, oleh karena itu apabila laba sebelum pajak tahun berjalan memiliki pengaruh pada laba sebelum pajak tahun depan maka laba tersebut dapat dikatakan persisten. Hasil analisis regresi sederhana dapat dilihat pada Tabel 1. 
Tabel 1. Hasil Analisis Regresi Sederhana

\begin{tabular}{|c|c|c|c|c|c|}
\hline \multirow{2}{*}{ Variabel } & \multicolumn{2}{|c|}{ Unstandardized Coefficients } & \multirow{2}{*}{$\begin{array}{l}\text { Standardized } \\
\text { Coefficients beta }\end{array}$} & \multirow[b]{2}{*}{$t$} & \multirow[b]{2}{*}{ Sig. } \\
\hline & $\mathrm{B}$ & Std. Error & & & \\
\hline (Constant) & 0,063 & 0,027 & & 2,352 & 0,025 \\
\hline PTBI $t$ & 0,356 & 0,171 & 0,336 & 2,079 & 0,045 \\
\hline
\end{tabular}

Sumber: Data Penelitian, 2019

Berdasarkan hasil analisis regresi sederhana pada Tabel 1 dapat dibuat persamaan regresi sebagi berikut.

$$
\text { PTBI }_{t+1}=0,063+0,356 \text { PTBI }_{t}
$$

Persamaan regresi tersebut digunakan untuk mengukur nilai persistensi laba pada masing-masing perusahaan yang menjadi sampel dalam penelitian ini. Selain itu, hasil regresi sederhana pada tabel 1 menunjukkan bahwa nilai signifikansi dari laba sebelum pajak tahun berjalan $\left(\mathrm{PTBI}_{\mathrm{t}}\right)$ sebesar 0,045 lebih kecil dari 0,05. Hal ini menunjukkan bahwa terdapat pengaruh positif antara laba sebelum pajak tahun berjalan $\left(\mathrm{PTBI}_{\mathrm{t}}\right)$ dengan laba sebelum pajak tahun depan $\left(\mathrm{PTBI}_{\mathrm{t}+1}\right)$. Maka dari itu dapat disimpulkan bahwa terdapat persistensi laba pada perusahaan transportasi yang menjadi sampel dalam penelitian ini.

Statistik deskriptif digunakan untuk memberikan gambaran atau deskripsi mengenai data yang diteliti dengan cara mendeskripsikan data yang telah terkumpul sebagaimana adanya tanpa bermaksud membuat kesimpulan yang berlaku untuk umum atau generalisasi (Sugiyono, 2017:232). Pengujian statistik deskriptif dilakukan sebelum melakukan pengujian hipotesis penelitian. Pada penelitian ini, peneliti memberikan gambaran data dilihat dari nilai rata rata (mean), maksimum, minimum, dan standar deviasi. Statistik deskriptif dalam penelitian ini menggambarkan nilai statistik dari variabel tingkat hutang, fee audit, konsentrasi pasar dan persistensi laba. Hasil analisis statistik deskriptif dapat dilihat pada Tabel 2.

\section{Tabel 2. Hasil Analisis Statistik Deskriptif}

\begin{tabular}{llllll}
\hline Variabel & N & Minimum & Maximum & Mean & $\begin{array}{l}\text { Std. } \\
\text { Deviation }\end{array}$ \\
\hline Persistensi Laba $(\mathrm{Y})$ & 36 & 0,07 & 0,29 & 0,0971 & 0,04469 \\
Tingkat Hutang $\left(\mathrm{X}_{1}\right)$ & 36 & 0,08 & 0,86 & 0,5146 & 0,19173 \\
Fee Audit $\left(\mathrm{X}_{2}\right)$ & 36 & 180,00 & 9424,00 & 3412,9167 & 1970,54083 \\
Konsentrasi Pasar $\left(\mathrm{X}_{3}\right)$ & 36 & 0,01 & 0,50 & 0,1388 & 0,12446 \\
Valid N (listwise) & 36 & & & & \\
\hline
\end{tabular}

Sumber: Data Penelitian, 2019

Hasil statistik deskriptif di atas menampilkan variabel persistensi laba mempunyai nilai minimum sebesar 0,07 yang dimiliki oleh PT. Adi Sarana Armada Tbk artinya persistensi laba minimum perusahaan transportasi pada tahun 2014-2017 yang menjadi sampel dalam penelitian ini adalah sebesar 0,07. Nilai maksimum sebesar 0,29 yang dimiliki oleh PT. Hupuss Internoda Transportasi Tbk artinya persistensi laba maksimum perusahaan transportasi pada tahun 2014-2017 yang menjadi sampel dalam penelitian ini adalah sebesar 0,29 . Nilai rata-rata persistensi laba sebesar 0,0971. Nilai rata-rata persistensi laba lebih mengarah ke nilai minimum, hal ini berarti rata-rata persistensi laba pada perusahaan transportasi yang menjadi sampel dalam penelitian ini cenderung rendah. Nilai standar deviasi sebesar 0,04469 lebih kecil dari pada nilai rata-rata 
artinya terdapat fluktuasi yang rendah pada persistensi laba di perusahaan transportasi yang menjadi sampel dalam penelitian ini.

Variabel tingkat hutang mempunyai nilai minimum sebesar 0,08 yang dimiliki oleh PT. Pelayaran Nelly Dwi Putri Tbk artinya tingkat hutang minimum perusahaan transportasi pada tahun 2014-2017 yang menjadi sampel dalam penelitian ini adalah sebesar 0,08. Nilai maksimum sebesar 0,86 yang dimiliki oleh PT. Hupuss Internoda Transportasi Tbk artinya tingkat hutang maksimum perusahaan transportasi pada tahun 2014-2017 yang menjadi sampel dalam penelitian ini adalah sebesar 0,86. Nilai rata-rata tingkat hutang sebesar 0,5146. Nilai rata-rata tingkat hutang lebih mengarah ke nilai maksimum, hal ini berarti rata-rata tingkat hutang pada perusahaan transportasi yang menjadi sampel dalam penelitian ini cenderung besar. Nilai standar deviasi sebesar 0,19173 lebih kecil dari pada nilai rata-rata artinya terdapat fluktuasi yang rendah pada tingkat hutang di perusahaan transportasi yang menjadi sampel dalam penelitian ini.

Variabel fee audit mempunyai nilai minimum sebesar 180,00 yang dimiliki oleh PT. Pelayaran Nelly Dwi Putri Tbk artinya fee audit minimum perusahaan transportasi pada tahun 2014-2017 yang menjadi sampel dalam penelitian ini adalah sebesar 180,00. Nilai maksimum sebesar 9424,00 yang dimiliki oleh PT. Samudera Indonesia Tbk artinya fee audit maksimum perusahaan transportasi pada tahun 2014-2017 yang menjadi sampel dalam penelitian ini adalah sebesar 9424,00. Nilai rata-rata fee audit sebesar 3412,9167. Nilai rata-rata fee audit lebih mengarah ke nilai minimum, hal ini berarti rata-rata fee audit pada perusahaan transportasi yang menjadi sampel dalam penelitian ini cenderung rendah. Nilai standar deviasi sebesar 1970,54083 lebih kecil dari pada nilai rata-rata artinya terdapat fluktuasi yang rendah pada fee audit di perusahaan transportasi yang menjadi sampel dalam penelitian ini.

Variabel konsentrasi pasar mempunyai nilai minimum sebesar 0,01 yang dimiliki oleh PT. Pelayaran Nelly Dwi Putri Tbk artinya konsentrasi pasar minimum perusahaan transportasi pada tahun 2014-2017 yang menjadi sampel dalam penelitian ini adalah sebesar 0,01. Nilai maksimum sebesar 0,50 yang dimiliki oleh PT. Samudera Indonesia Tbk artinya konsentrasi pasar maksimum perusahaan transportasi pada tahun 2014-2017 yang menjadi sampel dalam penelitian ini adalah sebesar 0,50. Nilai rata-rata konsentrasi pasar sebesar 0,1388. Nilai rata-rata konsentrasi pasar lebih mengarah ke nilai minimum, hal ini berarti rata-rata konsentrasi pasar pada perusahaan transportasi yang menjadi sampel dalam penelitian ini cenderung rendah. Nilai standar deviasi sebesar 0,12446 lebih kecil dari pada nilai rata-rata artinya terdapat fluktuasi yang rendah pada konsentrasi pasar di perusahaan transportasi yang menjadi sampel dalam penelitian ini.

Sebelum dilakukannya analisis regresi linier berganda, data variabel fee audit yang sebelumnya disajikan dalam skala rupiah terlebih dahulu di rubah menjadi data yang berskala rasio dengan menggunakan rumus logaritma. Perubahan tersebut dilakukan karena data yang berskala rasio atau interval merupakan data yang harus digunakan dalam melakukan analisis regresi linier berganda. Hasil analisis regresi linier berganda dapat dilihat pada Tabel 3. 
Tabel 3. Hasil Analisis Regresi Linier Berganda

\begin{tabular}{llll}
\hline \multirow{2}{*}{ Variabel } & \multicolumn{2}{l}{ Unstandardized Coefficients } & \multirow{2}{*}{ Sig. } \\
& $\mathrm{B}$ & Std. Error & \\
\hline (Constant) & $-0,044$ & 0,034 & 0,204 \\
Tingkat Hutang $\left(\mathrm{X}_{1}\right)$ & 0,084 & 0,028 & 0,005 \\
Fee Audit $\left(\mathrm{X}_{2}\right)$ & 0,024 & 0,011 & 0,044 \\
Konsentrasi Pasar $\left(\mathrm{X}_{3}\right)$ & 0,134 & 0,042 & 0,003 \\
Adjusted R Square & 0,681 & & \\
$\mathrm{~F}$ & 25,932 & & \\
F Sig. & 0,000 & & \\
\hline
\end{tabular}

Sumber: Data Penelitian, 2019

Berdasarkan hasil analisis regresi linier berganda pada tabel 3 diperoleh model regresi berganda yang terbentuk pada penelitian ini adalah sebagai berikut:

$$
Y=-0,044+0,084 X_{1}+0,024 X_{2}+0,134 X_{3}
$$

Model regresi berganda diatas menunjukkan bahwa nilai konstanta sebesar -0,044 yang memiliki arti apabila tingkat hutang, fee audit, dan konsentrasi pasar sama dengan 0 maka nilai persistensi laba sama dengan -0,044. Nilai koefisien variabel tingkat hutang bernilai positif sebesar 0,084 yang berarti apabila nilai tingkat hutang naik satu satuan maka persistensi laba akan naik sebesar 0,084 dengan asumsi variabel lainnya konstan. Nilai koefisien variabel fee audit bernilai positif sebesar 0,024 yang berarti apabila nilai fee audit naik satu satuan maka persistensi laba akan naik sebesar 0,024 dengan asumsi variabel lainnya konstan. Nilai koefisien variabel konsentrasi pasar bernilai positif sebesar 0,134 yang berarti apabila nilai konsentrasi pasar naik satu satuan maka persistensi laba akan naik sebesar 0,134 dengan asumsi variabel lainnya konstan.

Berdasarkan tabel 3 dapat dilihat nilai $F$ hitung sebesar 25,932 dengan tingkat signifikansi sebesar 0,000 lebih kecil dari 0,05. Hasil ini menunjukkan model regresi yang terdapat dalam penelitian ini layak digunakan serta terdapat pengaruh secara simultan antara tingkat hutang, fee audit, dan konsentrasi pasar pada persistensi laba.

Berdasarkan tabel 3 nilai adjusted $\mathrm{R}^{2}$ sebesar 0,681, ini berarti sebesar 68.1\% variasi variabel tingkat hutang, fee audit, dan konsentrasi pasar dapat menjelaskan variabel persistensi laba, sedangkan sisanya sebesar 31,9 \% dapat dijelaskan oleh variabel-variabel lain diluar model penelitian.

Berdasarkan tabel 3 variabel tingkat hutang memiliki nilai koefisien regresi sebesar 0,084 dengan nilai signifikansi sebesar 0,005 lebih kecil dari 0,05 maka $\mathrm{H}_{1}$ diterima dan $\mathrm{H}_{0}$ ditolak yang menjelaskan bahwa tingkat hutang berpengaruh positif pada persistensi laba. Hal ini menunjukkan bahwa ketika perusahaan mempunyai tingkat hutang yang tinggi, perusahaan akan meningkatkan persistensi laba dengan tujuan untuk mempertahankan kinerja perusahaan yang baik dimata kreditor. Dengan adanya perolehan laba yang persisten pada perusahaan diharapkan kreditor tetap memiliki kepercayaan terhadap perusahaan dan tetap memberikan pinjaman dana kepada perusahaan, sehingga perusahaan dapat memperoleh kemudahan dalam proses pembayaran. Begitu juga kepada investor, Perolehan laba yang persisten pada perusahaan dapat memberikan informasi kepada investor bahwa perusahaan mampu 
mempertahankan laba di masa mendatang meskipun biaya yang dikeluarkan perusahaa bertambah yaitu biaya bunga atas pinjaman. Hasil penelitian ini sejalan dengan penelitian yang dilakukan oleh Putri \& Supadmini (2016) serta Fitriana \& Fadhila (2016) yang meneliti pengaruh tingkat hutang pada persistensi laba di perusahaan manufaktur dan perusahaan property \& real estate, dimana hasil dari penelitian tersebut menyatakan bahwa tingkat utang berpengaruh positif pada persistensi laba. Namun tidak sejalan dengan penelitian yang dilakukan oleh Arisandi \& Astika (2019)yang menghasilkan tingkat utang tidak berpengaruh pada persistensi laba di perusahaan property \& real estate.

Berdasarkan Tabel 3 variabel fee audit memiliki nilai koefisien regresi sebesar 0,024 dengan nilai signifikansi sebesar 0,044 lebih kecil dari 0,05 maka $\mathrm{H}_{2}$ diterima dan $\mathrm{H}_{0}$ ditolak yang menjelaskan bahwa fee audit berpengaruh positif pada persistensi laba. Hal ini menunjukkan bahwa semakin tinggi fee audit yang dibayarkan maka persistensi laba akan semakin meningkat. Karena pemberian fee audit yang tinggi kepada auditor independen akan meningkatkan ketelitian auditor serta dapat tersedia cukup dana untuk penelitian dan penerapan prosedur audit yang lebih luas dan seksama. Dengan adanya tingkat ketelitian yang tinggi dari auditor serta auditor dapat memperluas prosedur audinya, manajemen perusahaan akan termotivasi untuk meningkatkan kinerja perusahaannya dengan melaporkan laba yang persisten. Hasil penelitian ini mendukung penelitian yang dilakukan oleh El-Gammal (2012) yang membuktikan bahwa perusahaan multinasional dan bank-bank di labanon lebih memilih memberikan fee audit yang besar kepada auditor independen dari suatu KAP yang dapat memberikan hasil audit yang berkualitas sehingga perusahaan dapat mencerminkan terjadinya persistensi laba. Hasil penelitian ini juga sejalan dengan penelitian yang dilakukan oleh Nuraeni et al (2018) yang menyatakan bahwa fee audit berpengaruh positif terhadap perisistensi laba pada perusahaan property \& real estate.

Berdasarkan tabel 3 variabel konsentrasi pasar memiliki nilai koefisien regresi sebesar 0,134 dengan nilai signifikansi sebesar 0,003 lebih kecil dari 0,05 maka $\mathrm{H}_{3}$ diterima dan $\mathrm{H}_{0}$ ditolak yang menjelaskan bahwa konsentrasi pasar berpengaruh positif pada persistensi laba. Hal ini menunjukkan bahwa semakin tinggi konsentrasi pasar yang dimiliki maka akan meningkatkan perolehan laba yang persisten. Konsentrasi pasar perusahaan sangat erat kaitannya dengan pangsa pasar yang dikuasai oleh perusahaan, karena konsentrasi pasar merupakan persentase pangsa pasar yang dikuasai oleh perusahaan relatif terhadap pangsa pasar total. Semakin besar pangsa pasar yang dikuasai oleh perusahaan maka dapat dikatakan bahwa perusahaan tersebut mempunyai tingkat konsentrasi yang tinggi. Pangsa pasar bersinggungan langsung dengan laba karena didalam pangsa pasar terdapat kegiatan penjualan. Apabila tingkat penjualan perusahaan tinggi dan perusahaan dapat mempertahankan tingkat penjualannya maka akan memengaruhi perolehan laba yang persisten dalam perusahaan. Hasil penelitian ini sejalan dengan penelitian yang dilakukan oleh Fanani et al (2008) yang menyatakan bawah konsentrasi pasar berpengaruh positif terhadap kualitas pelaporan keuangan berbasis akuntansi yang diproksikan dengan persistensi, prediktibilitas dan perataan pada perusahaan manufaktur. Hasil penelitian ini juga dapat mendukung penelitian yang 
dilakukan oleh Nuraeni et al (2018) yang menyatakan bahwa konsentrasi pasar berpengaruh positif terhadap perisistensi laba pada perusahaan property \& real estate.

\section{SIMPULAN}

Berdasarkan hasil penelitian yang telah dilakukan dan pembahasan yang telah diuraikan pada bab sebelumnya, maka dapat ditarik kesimpulan bahwa tingkat hutang, fee audit, dan konsentrasi pasar berpengaruh positif pada persistensi laba di perusahaan transportasi yang terdaftar di BEI dari tahun 2014-2017.

Penelitian ini menggunakan perusahaan transportasi sebagai populasi penelitian. Penelitian berikutnya diharapkan dapat menggunakan populasi dari perusahaan lain seperti perusahaan pertambangan, perdagangan, jasa, dan investasi serta dapat menambahkan periode amatan karena hal ini akan memengaruhi hasil penelitian. Penelitian berikutnya juga diharapkan dapat menambahkan jumlah variabel lain yang dapat memengaruhi persistensi laba seperti book-tax differences, kepemilikan manajerial, ukuran perusahaan, besaran akrual, dan volatilitas aliran kas, karena nilai koefisien determinasi dalam penelitian ini menunjukkan bahwa masih terdapat 31,9\% indikator lain yang dapat memengaruhi persistensi laba.

\section{REFERENSI}

Achyarsyah, P., \& Purwanti, A. J. (2018). Pengaruh Perbedaan Laba Komersial dan Laba Fiskal, Pajak Tangguhan, dan Leverage Terhadap Persistensi Laba. Jurnal Ilmu Akuntansi, 16(2), 56-67.

Ali, A. M., Al-Shattarat, \& Yusuf, A. N. (2015). The Effects of Contextual Factors on Disaggregated Earnings in Explaining Dividend Changes in Jordanian Firms. International Journal of Commerce and Management, 25(2), 218-239. https:// doi.org/10.1108/IJCoMA-02-2013-0016

Arisandi, D., \& Astika, A. (2019). Pengaruh Tingkat Utang, Ukuran Perusahaan dan Kepemilikan Manajerial pada Persistensi Laba. E-Jurnal Akuntansi Universitas Udayana, 26(3), 1854 - 1884. https://doi.org/10.24843/eja.2019.v26.i03.p07

Catherine. (2013). Pengaruh Dewan Komisaris Independen, Komite Audit, Kepemilikan Manajerial dan Kualitas Audit terhadap Perataan Laba. Jurnal Akuntansi, 7(2).

Djajanti, A. (2017). Pengaruh Faktor Internal dan Persistensi Laba Pada Perataan Laba Bank BUMN di Indonesia. Jurnal Penelitian dan Karya Ilmiah Lemlit, 2(2), 1-12.

El-Gammal, W. (2012). Determinants of Audit Fees: Evidence from Lebanon. International Business Research, 5(11), 136-145. https://doi.org/10.5539/ibr.v5n11p136

Enekwe, C. I., Agu, C. I., \& Nagbogu, E. K. (2014). The Effect of Financial Leverage on Financial Performance: Evidence of Quoted Pharmaceutical Companies in Nigeria. IOSR Journal of Economics and Finance, 5(3), 17-25.

Fanani, Z., Ningsih, S., \& Hamidah. (2008). Faktor-faktor Penentu Kualitas Pelaporan Keuangan dan Kepercayaan Investor. Departemen 
Akuntansi, Fakultas Ekonomi, Universitas Airlangga, Indonesia, 1-32. https://doi.org/https://doi.org/10.1192/bjp.111.479.1009-a

Fitriana, N., \& Fadhila, W. (2016). Pengaruh Tingkat Hutang dan Arus Kas Akrual Terhadap Persistensi Laba. Jurnal Ilmiah Mahasiswa Ekonomi Akuntansi, 1(1), 258-272.

Hui, K. W., Nelson, K. K., \& Yeung, P. E. (2016). On The Persistence and Pricing of Industry-Wide and Firm-Specific Earnings, Cash Flows, and Accruals. Journal of Accounting and Economics, 61(1), 185-202. https://doi.org/http:/ /dx.doi.org/10.1016/j.jacceco.2015.06.003

IDX. (2019). Profil Perusahaan Tercatat. Diakses Pada 30 April 2019, dari https://idx.co.id/perusahaan-tercatat/profil-perusahaan-tercatat/

Jensen, M., \& Meckling, W. (2012). Theory of the firm: Managerial behavior, agency costs, and ownership structure. The Economic Nature of the Firm: A Reader, Third Edition, 3(1), 283-303. https://doi.org/10.1017/CBO9780511817410.023

Jumiati, F., \& Ratnadi, N. M. D. (2014). Pengaruh Kepemilikan Manajerial Dan Book Tax Differences Pada Persistensi Laba. E-Jurnal Akuntansi Universitas Udayana, 8(2), 91-101.

KKP. (2017). Maritim Indonesia, Kemewahan Yang Luar Biasa. Diakses pada 8 oktober 2019, dari http://www2.kkp.go.id/artikel/2233-maritimindonesia-kemewahan-yang-luar-biasa

Koch, B.S. (1981). Income Smoothing: An Experiment. The Accounting Review, LVI(3)

Kolozsvari, A. C. (2016). Analysis of the Influence of Income Smoothing Over Earnings Persistence in the Brazilian Market. R. Cont. Fin. - USP, São Paulo, 27(72), 306-319. https://doi.org/10.1590/1808-057x201602610

Kordestani, G., Taqiporian, M., Biglari, V., \& Minaei, V. (2016). Persistences of Earnings and Prediction of Future Cash Flows : The Role of Timely Recognition of Bad News. Business: Theory and Practice, 17(4), 353360. https:// doi.org/10.3846/btp.17.11124

Laily, W., \& Ahmar, N. (2014). The Effect of Earnings Persistence on Company Performance in Manufacturing Companies Listed on the Indonesian Stock Exchange. The Indonesian Accounting Review, 4(1), 37-42.

Martinez, A. L., Tatiana, B. T. S., \& Danilo, S. M. (2015). Book-Tax Differences, Earnings Persistences and Tax Planning Before and After The Adoption of IFRS in Brazil. Advances in Scientific and Aplied Accounting Journal, 9(8), 1-18.

Nuraeni, R., Mulyati, S., \& Putri, T. E. (2018). Faktor-faktor yang Mempengaruhi Persistensi Laba (Studi Kasus pada Perusahaan Property dan Real Estate yang Terdaftar di Bursa Efek Indonesia Tahun 2013-2015). Accruals, 2(1), 82-112. https:/ / doi.org/10.35310/accruals.v2i1.8

Nuswatara, D. A. (2004). The Effect of Market Share and Leverage Interaction Toward Earnings Management Practices. Jurnal Dan Prosiding SNA Simposium Nasional Akuntansi, 7, 170-185. Retrieved from http:/ / pdeb.fe.ui.ac.id/?p=6848 
Putri, G., \& Supadmi, N. L. (2016). Pengaruh Tingkat Hutang dan Kepemilikan Manajerial Terhadap Persistensi Laba Pada Perusahaan Manufaktur. E-Jurnal Akuntansi Universitas Udayana, 15(2), 915-942.

Rahmadhani, A., Zulbahridar, \& Hariadi. (2016). Pengaruh Book-tax Differences, Volatilitas Arus Kas, Volatilitas Penjualan, Besaran Akrual, dan Tingkat Hutang Terhadap Persistensi Laba (Studi Empiris pada Perusahaan Aneka Industri yang terdaftar di BEI tahun 2010-2014). Jurnal Online Mahasiswa Fakultas Ekonomi Universitas Riau, 3(1), 21632176.

Sari, S. P., \& Fachrurrozie. (2016). The Analysis of Factors and Moderation of Book Tax Difference On The Property Real Estate. Accounting Analysis Journal, 5(3), 182-188.

Scott, W. R. (1997). Financial Accounting Theory Second edition. In Canada: Prentice Hall.

Sugiyono. (2017). Pendekatan Kuantitatif, Kualitatif, Kombinasi, R\&D dan Penelitian Evaluasi. In Alfabeta.

Sulastri, D. A. (2014). Pengaruh Volatilitas Arus Kas dan Tingkat Hutang Terhadap Persistensi Laba. E-Journal UNP, 2(2), 1-29.

Sutisna, H. (2017). Accruals and Cash Flow Volatility of The Earnings Persistence. International Journal of Economic Perspectives, 11(1), 1558-1570.

Utari, L. A. P., \& Mertha, M. (2016). Corporate Governance Memoderasi Pengaruh Book Tax Differences pada Persistensi Laba. E-Jurnal Akuntansi Universitas Udayana, 16(2), 1376-1404.

Vichitsarawong, T., \& Sompong, P. (2015). Do Audit Opinions Reflect Earnings Persistence?. Managerial Auditing Journal, 30(3), 244-276. https:// doi.prg/10.1108/MAJ-12-2013-0973

Yosra, B. M. (2015). Earnings Volatility and Earnings Predictability. Journal of Business Studies Quarterly, 6(3), 37-53.

Zdulhiyanov, M. (2015). Pengaruh Book Tax Differences terhadap Persistensi Laba (Studi Empiris pada Perusahaan Manufaktur yang Terdaftar di Bursa Efek Indonesia Tahun 2008 - 2011). -Urnal Akuntansi Universitas Negeri Padang, 3(1), 55-67.

Zhou, M. (2016). Does Accounting For Uncertain Tax Benefits Provide Information About The Relation Between Book-Tax Differences and Earnings Persistence? Review of Accounting and Finance, 15(1), 65-84. https://doi.org/https:// doi.org/10.1108/RAF-05-2014-0054 